\title{
Chromosomal abnormalities and neurological outcomes in fetal cerebral ventriculomegaly: a retrospective cohort analysis
}

\author{
WY Lok *, CW Kong, SYA Hui, MM Shi, KW Choy, WK To, TY Leung
}

\section{A B S T R A C T}

Introduction: This study investigated the incidences of chromosomal abnormalities and the neurological outcomes according to the degree of fetal cerebral ventriculomegaly.

Methods: All women with antenatal ultrasound diagnosis of fetal cerebral ventriculomegaly were retrospectively identified from two maternal-fetal medicine units in Hong Kong from January 2014 to December 2018. Degrees of fetal ventriculomegaly were classified as mild (10-11.9 mm), moderate $(12-14.9 \mathrm{~mm})$, or severe $(\geq 15 \mathrm{~mm})$. Genetic investigation results were reviewed, including conventional karyotyping and chromosomal microarray analysis (CMA); correlations between chromosomal abnormalities and the degree of fetal ventriculomegaly were explored. The neurological outcomes of subsequent live births were analysed to identify factors associated with developmental delay.

Results: Of 84 cases (ie, pregnant women and their fetuses) included, 46 (54.8\%) exhibited isolated fetal ventriculomegaly, 55 (65.5\%) had mild cerebral ventriculomegaly, and 29 (34.5\%) had moderate or severe cerebral ventriculomegaly. Overall, 20\% (14/70) of cases had chromosomal abnormalities. Moreover, 12\% (3/25) of mild isolated ventriculomegaly cases had abnormal karyotype or CMA results. The CMA provided an incremental diagnostic yield of $8.6 \%(6 / 70)$, compared with conventional karyotyping; $4.3 \%$ exhibited pathogenic variants and $4.3 \%$ exhibited variants of uncertain significance. Among the 53 live births in the cohort, fewer cases of mild isolated ventriculomegaly were associated with developmental delay than more severe isolated ventriculomegaly $(9.7 \%$ vs $41.7 \%$, $\mathrm{P}<0.03)$.

Conclusions: Chromosomal microarray analysis testing should be offered to all women with fetal cerebral ventriculomegaly, including women with isolated mild ventriculomegaly. The incidence of developmental delay after birth increases with the degree of prenatal cerebral ventriculomegaly.

\section{Hong Kong Med J 2021;27:428-36 \\ https://doi.org/10.12809/hkmj208850}

${ }^{1}$ WY Lok *, FHKAM (Obstetrics and Gynaecology), FHKCOG

${ }^{1}$ CW Kong, FHKAM (Obstetrics and Gynaecology), FHKCOG

2 SYA Hui, FHKAM (Obstetrics and Gynaecology), FHKCOG

${ }^{2}$ MM Shi, MPhil

${ }^{2}$ KW Choy, PhD

WK To, MD, FRCOG

2 TY Leung, MD, FRCOG

\begin{abstract}
Department of Obstetrics and Gynaecology, United Christian Hospital, Hong Kong

2 Department of Obstetrics and Gynaecology, The Chinese University of Hong Kong, Hong Kong
\end{abstract}

* Corresponding author: happyah2@hotmail.com

\section{New knowledge added by this study}

- All degrees of isolated cerebral ventriculomegaly were associated with chromosomal abnormalities; the incidences of chromosomal abnormalities did not significantly differ according to the degree of ventriculomegaly.

- Chromosomal microarray analysis (CMA) provided an incremental diagnostic yield of 8.6\%, compared with conventional karyotyping, for fetal cerebral ventriculomegaly.

Implications for clinical practice or policy

- Invasive procedures with CMA testing should be offered to all women with fetal cerebral ventriculomegaly.

- Non-invasive prenatal testing for chromosome abnormalities should not be offered as an alternative to direct invasive genetic testing.

- Women should receive counselling for the neurological outcomes of the children according to the degree of fetal cerebral ventriculomegaly.

\section{Introduction}

Assessment of the fetal cerebral lateral ventricle is a standard requirement during the mid-trimester morphology ultrasound performed between 18 and 22 weeks of gestation. ${ }^{1}$ The International Society of Ultrasound in Obstetrics and Gynecology has recommended a standard method to measure the size of the lateral ventricle, which should be in an axial transventricular plane at the atrium of the posterior horn with calibres placed over the inner 
edges. $^{2}$ The reference ranges of lateral ventricle width were established by Cardoza et $\mathrm{al}^{3}$ in 1988; they are consistent across gestations. The diameter (mean \pm standard deviation) of the lateral ventricle is $7.6 \pm 0.6 \mathrm{~mm}$ (range, 6-9). Therefore, fetal cerebral ventriculomegaly is defined as dilation of the lateral ventricle atrium to a width of $>10 \mathrm{~mm}$ ( $>4$ standard deviations from the mean). ${ }^{3}$

The degree of lateral ventricle dilation is classically categorised as mild (10-11.9 mm), moderate $(12-14.9 \mathrm{~mm})$, or severe $(\geq 15 \mathrm{~mm})$ for clinical and research purposes. Mild fetal ventriculomegaly can be isolated and may represent a normal variant if other pathologies are excluded. ${ }^{4}$ Therefore, the identification of cerebral ventriculomegaly on prenatal ultrasound does not represent a conclusive diagnosis; it signifies a need to identify various underlying pathologies, including structural abnormalities of the central nervous system (CNS), from hypoxic, haemorrhagic, infective, and genetic causes. Fetal ventriculomegaly is considered a marker of abnormal karyotype; it can be associated with pathogenic copy number variations (CNVs) identified by chromosomal microarray analysis (CMA). The Society for Maternal Fetal Medicine recommends antenatal diagnostic testing (amniocentesis) with CMA when ventriculomegaly is detected. ${ }^{4}$ In this study, we examined the incidences of abnormal karyotype and CMA results in fetuses with cerebral ventriculomegaly in Hong Kong; we also evaluated their correlations with different degrees of ventriculomegaly. We aimed to determine whether amniocentesis with CMA should be offered to all fetuses with cerebral ventriculomegaly, regardless of the degree of ventriculomegaly. We also reviewed the neurodevelopmental outcomes of all live births with fetal ventriculomegaly to identify factors associated with developmental delay.

\section{Methods}

This retrospective cohort study included all pregnant women with antenatal ultrasound diagnosis of fetal cerebral ventriculomegaly from two maternal-fetalmedicine units in tertiary referral public obstetric centres in Hong Kong, United Christian Hospital and Prince of Wales Hospital, from January 2014 to December 2018. Cases of fetal ventriculomegaly were identified from the registries of prenatal ultrasound structural abnormalities, as well as the antenatal ultrasound and invasive procedures databases of the respective departments; they were also identified from the laboratory genetic diagnosis database of the Chinese University of Hong Kong (CUHK). All cases of fetal ventriculomegaly in the two units were carefully analysed by the maternal fetal medicine specialists, in accordance with standard departmental protocols. Fetal cerebral ventriculomegaly was classified as mild $(10-11.9 \mathrm{~mm})$,

\section{胎兒腦室擴大的染色體異常和神經系統結果： 回顧性隊列分析}

駱詠怡、江采華、許淑儀、史蒙蒙、蔡光偉、杜榮基、梁德楊 引言：本研究根據胎兒腦室擴大的程度檢視染色體異常的發生率和神 經系統結果。

方法：對所有2014年1月至2018年12月期間在香港兩間母胎醫學中 心經產前超聲波診斷為胎兒腦室擴大的孕婦進行回顧性鑑定。胎兒 腦室擴大程度分為輕度（10-11.9毫米）、中度（12-14.9毫米）或嚴 重 $(\geq 15$ 毫米) 。分析遺傳結果包括常規核型分析和染色體微陣列分 析, 並探討染色體異常與胎兒腦室擴大程度之間的相關性。分析隨後 活產兒的神經系統結果, 以確定與發育遲緩相關的因素

結果：共納入 84 例（即孕婦及其胎兒），其中46例（54.8\%）為孤立 性胎兒腦室擴大； 55 例（65.5\%）有輕度腦室擴大，29例（34.5\%） 有中度或嚴重腦室擴大。總體而言, $20 \%$ （14/70）的病例有染色體異 常。此外, $12 \%(3 / 25)$ 的輕度孤立性腦室擴大病例有異常核型或染 色體微陣列分析結果。與傳統核型分析相比, 染色體微陣列分析提供 8.6\%（6/70）的增量診斷率; $4.3 \%$ 表現出致病性變異, $4.3 \%$ 表現出意 義不明的變異。53名活產兒中, 輕度孤立性腦室擴大導致發育遲緩的 比例較嚴重孤立性腦室擴大為低 $(9.7 \%$ 比 $41.7 \%, \mathrm{P}<0.03)$

結論：染色體微陣列分析測試應提供給所有胎兒腦室擴大的孕婦, 包 括胎兒輕度孤立性腦室擴大的孕婦。出生後發育遲緩的發生率亦隨着 產前腦室擴大的嚴重性而增加。

moderate $(12-14.9 \mathrm{~mm})$, or severe $(\geq 15 \mathrm{~mm})$, according to the greatest atrial width observed during ultrasound examinations in that pregnancy. Based on assessments of any associated ultrasound abnormalities, fetal cerebral ventriculomegaly was classified as isolated (if cerebral ventriculomegaly was the only abnormality identified) or non-isolated (if other structural abnormalities were detected, including CNS abnormalities of the brain or spine and abnormalities in other organ systems).

Pregnant women who chose amniocentesis underwent karyotyping as the standard primary genetic investigation. Chromosomal microarray analysis was offered as an additional self-financed test. The genetic samples of patients from United Christian Hospital were sent to the Prenatal Diagnostic Laboratory of Tsan Yuk Hospital; the genetic samples of patients from Prince of Wales Hospital were sent to the Prenatal Diagnostic Genetic Diagnosis Centre of the CUHK. The microarray platform Perkin Elmer CGX V2.0 (60K oligonucleotide array) and Affymetrix CytoScan $750 \mathrm{~K}$ single nucleotide polymorphism array were used for CMA studies in Tsan Yuk Hospital from January 2014 to September 2018 and from October to December 2018, respectively; the Agilent Fetal DNA chip version $2.0(8 \times 60 \mathrm{k})$ array comparative genomic hybridisation and single nucleotide polymorphism analysis methods were used in the CUHK throughout the study period. The neurodevelopmental outcomes 
of live births were reviewed using the hospital's computerised clinical management system. Each child's development was assessed by a paediatrician during follow-up; assessments determined the presence of cognitive impairment, speech delay, fine and gross motor skills, epilepsy, or developmental delay.

The study protocol was approved by the research ethics committees of the respective hospitals. The Strengthening the Reporting of Observational Studies in Epidemiology (STROBE) statement was used as a reporting guideline for this study. SPSS software (Windows version 20.0; IBM Corp, Armonk [NY], United States) was used for data entry and analysis. Comparisons of categorical variables were performed using the Chi squared test or Fisher's exact test, as appropriate. A P value of $<0.05$ was considered statistically significant.

\section{Results}

From January 2014 to December 2018, there were 55565 total deliveries in the study centres; 91 fetuses (0.16\%) had antenatal ultrasound diagnosis of cerebral ventriculomegaly. After the exclusion of cases (ie, pregnant women and their fetuses) with incomplete information (eg, incomplete ultrasound details) and cases that had not delivered in the study units, 84 cases were included for final analysis. The maternal and fetal characteristics are shown in Table 1. Overall, 65.5\% (55/84) of fetuses exhibited mildly dilated lateral ventricles and $54.8 \%$ (46/84) of fetuses exhibited isolated ventriculomegaly. More male fetuses had cerebral ventriculomegaly than did female fetuses $(63.1 \%$ vs $36.9 \%)$. Screening for congenital fetal infections (eg, cytomegalovirus in amniotic fluid, maternal blood, or urine; toxoplasmosis in maternal blood) was conducted in $66.7 \%$ of all cases (73.9\% of isolated ventriculomegaly cases); all had negative results. Infection screening was often not performed in cases of non-isolated fetal ventriculomegaly associated with other structural abnormalities; abnormalities in those cases were often presumed to be associated with genetic causes, rather than infection. Fetal magnetic resonance imaging (MRI) was performed in 16 cases (19.0\%) to detect additional CNS abnormalities. The most common CNS abnormalities associated with ventriculomegaly were Dandy-Walker malformation (7 cases), corpus callosum disorders (5 cases), and spina bifida (3 cases). Other CNS abnormalities identified included brain tumour, occipital encephalocele, aqueductal stenosis, lissencephaly, and schizencephaly. The pregnancy outcomes are shown in the Figure. In total, 53 live births were delivered in our cohort at a mean gestational age of $38.1 \pm 1.9$ weeks. The mean birth weight was $3043 \pm 614 \mathrm{~g}$. The mean age at neurodevelopmental outcome assessment of the children was 33 months
TABLE I. Maternal and fetal characteristics of cases with fetal cerebral ventriculomegaly $(n=84)^{*}$

\begin{tabular}{|c|c|}
\hline Maternal Chinese ethnicity & $80(95.2 \%)$ \\
\hline Maternal age, y & $32.4 \pm 5.6$ \\
\hline Gestational age at first diagnosis, wk & $20.8 \pm 3.3$ \\
\hline Diagnosis before 24 weeks & $74(88.1 \%)$ \\
\hline \multicolumn{2}{|l|}{ Laterality } \\
\hline Unilateral & $33(39.3 \%)$ \\
\hline Left & 22 \\
\hline Right & 11 \\
\hline Bilateral & $51(60.7 \%)$ \\
\hline \multicolumn{2}{|l|}{ Severity } \\
\hline Mild (10-11.9 mm) & $55(65.5 \%)$ \\
\hline Moderate (12-14.9 mm) & $18(21.4 \%)$ \\
\hline Severe $(\geq 15 \mathrm{~mm})$ & $11(13.1 \%)$ \\
\hline \multicolumn{2}{|l|}{ Ultrasound features } \\
\hline Isolated cerebral ventriculomegaly & $46(54.8 \%)$ \\
\hline Non-isolated cerebral ventriculomegaly & $38(45.2 \%)$ \\
\hline CNS abnormalities & 21 \\
\hline Other abnormalities & 17 \\
\hline \multicolumn{2}{|l|}{ Fetal sex } \\
\hline Male & $53(63.1 \%)$ \\
\hline Female & $31(36.9 \%)$ \\
\hline
\end{tabular}

Abbreviation: CNS = central nervous system

Data are shown as No. (\%) or mean \pm standard deviation

(range, 14-72); ultrasound, computed tomography, or MRI scanning was performed after delivery in $56.6 \%(30 / 53)$ of the cases.

Amniocentesis was performed in $77.4 \%$ $(65 / 84)$ of cases. Among the 22.6\% (19/84) of cases that did not involve amniocentesis, an invasive test was declined in 10; in the remaining nine cases, fetal ventriculomegaly was detected after 24 weeks of gestation, which exceeded the legal limit for termination of pregnancy in Hong Kong. The karyotype and CMA results in four cases were obtained from placental tissue after termination of pregnancy; in one case, the results were obtained from the baby's peripheral blood after delivery. Altogether, karyotype results were available in 70 cases; CMAs were conducted in 53 of those cases. Fourteen cases (20\%) had abnormal karyotype or CMA results (Table 2). In total, $11.4 \%(8 / 70)$ of cases had chromosomal abnormalities that could be detected by conventional karyotyping alone, while six cases (shown in Table 2) had chromosomal abnormalities that could only be detected by CMA testing. Therefore, CMA provided an incremental diagnostic yield of $8.6 \%(6 / 70)$ compared with conventional karyotyping; three cases exhibited pathogenic CNVs $(4.3 \%, 3 / 70)$ and three cases exhibited variants of uncertain significance (VOUS) $[4.3 \%, 3 / 70]$. The three pathogenic CNVs included 


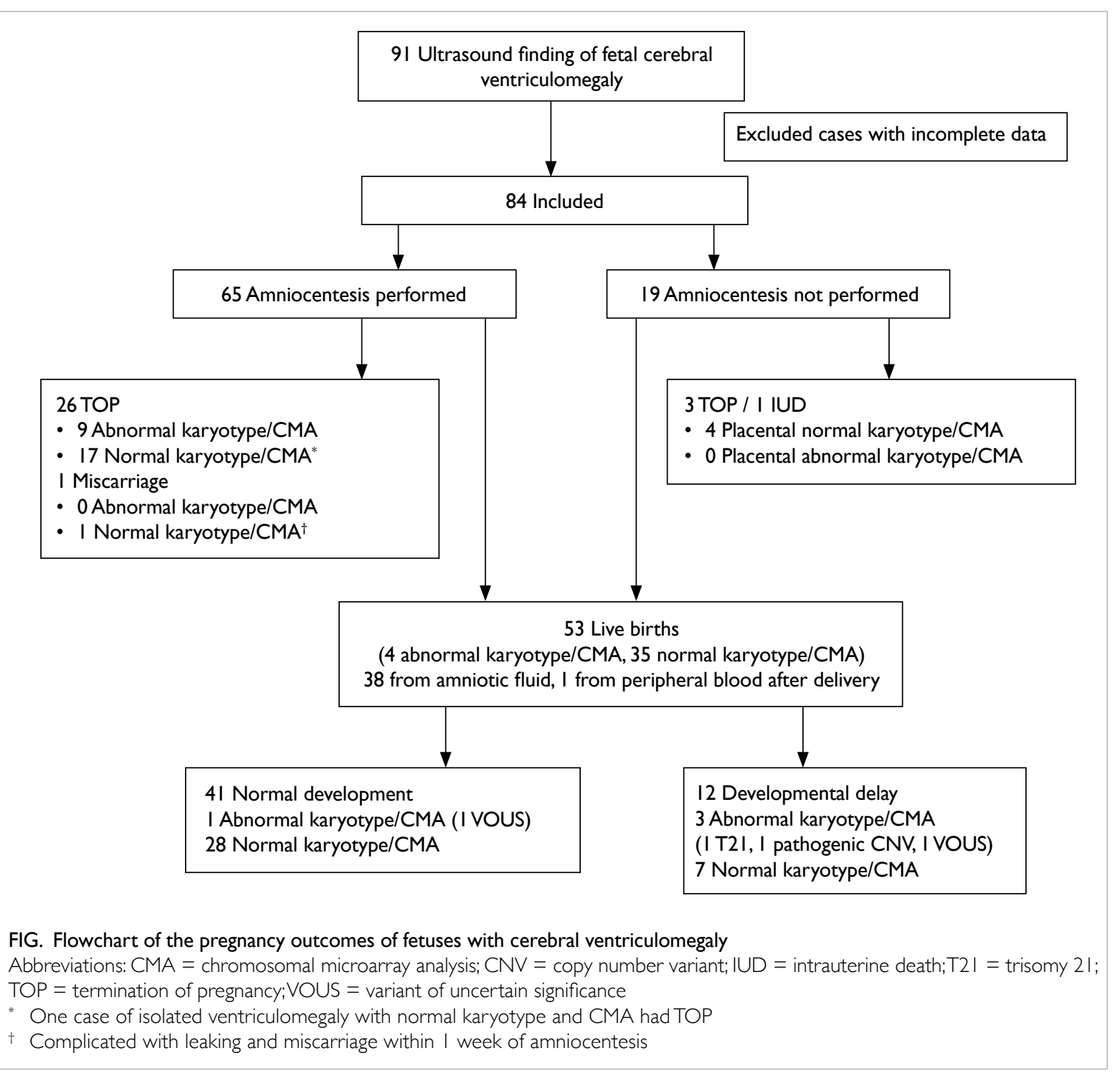

two cases of $17 \mathrm{p} 13.3$ deletion: one involved the lissencephaly 1 (LIS1) gene and one involved the YWHAE gene. Deletion of the LIS1 gene has been associated with classic lissencephaly, microcephaly, and mental insufficiency; YWHAE may be a susceptibility gene for schizophrenia. ${ }^{5}$ The third case of terminal $6 \mathrm{p} 25$ deletion involved the FOXC1 gene, which is reportedly associated with CNS anomalies (eg, hydrocephalus and hypoplasia of the cerebellum, brainstem, and corpus callosum) that cause mild to moderate developmental delay. ${ }^{6}$

Subgroup analysis showed that in the isolated cerebral ventriculomegaly group, $15.2 \%$ (5/33) of cases had abnormal karyotype or CMA results; the incidences of abnormal karyotype or CMA results did not significantly differ according to the degree of isolated cerebral ventriculomegaly $(\mathrm{P}=0.31)$ [Table 3]. In the mild isolated ventriculomegaly group, $12.0 \%$ $(3 / 25)$ of cases had abnormal karyotype or CMA results, among which two cases could be detected by conventional karyotyping and one case (VOUS) could only be detected by CMA.

Concerning the evolution of isolated ventriculomegaly with live births, $8.3 \%$ (3/36) with mild isolated ventriculomegaly and $20 \%(1 / 5)$ with moderate isolated ventriculomegaly at diagnosis showed progression during pregnancy. Fewer cases of mild cerebral ventriculomegaly (10-11.9 mm) were associated with developmental delay than nonmild ( $\geq 12 \mathrm{~mm}$ ) ventriculomegaly in the isolated ventriculomegaly group $(9.7 \%$ vs $41.7 \%$; $\mathrm{P}=0.03)$. Developmental delay tended to be more common in the isolated cerebral ventriculomegaly group with abnormal karyotype or CMA results $(66.7 \%$ vs $14.8 \%)$, compared with isolated ventriculomegaly with normal karyotype or CMA; however, this difference was not statistically significant. The risk of developmental delay was not significantly different according to fetal sex in cases of isolated ventriculomegaly (Table 4). The clinical details of the 12 cases with developmental delay are summarised in Table 5. 
TABLE 2. Cases of fetal ventriculomegaly with abnormal karyotyping or CMA and their outcomes

\begin{tabular}{|c|c|c|c|c|c|c|}
\hline Case & $\begin{array}{l}\text { Degree } \\
\text { of ventri- } \\
\text { culomegaly }\end{array}$ & $\begin{array}{l}\text { Other ultrasound } \\
\text { abnormalities }\end{array}$ & Karyotype result & CMA result & $\begin{array}{l}\text { Pregnancy } \\
\text { outcome }\end{array}$ & $\begin{array}{l}\text { Develop- } \\
\text { ment }\end{array}$ \\
\hline \multirow[t]{2}{*}{1} & \multirow[t]{2}{*}{ Mild } & \multirow[t]{2}{*}{ Isolated } & \multirow[t]{2}{*}{$\begin{array}{l}\operatorname{mos} 47, X Y,+i(12) \\
(p 10)[24] / 46, X Y[6]\end{array}$} & $\begin{array}{l}\text { arr[hg19] 12p13.33p11.1 } \\
(189,578-34,427,592) \times 3 \sim 4\end{array}$ & \multirow[t]{2}{*}{ TOP } & \multirow[t]{2}{*}{ NA } \\
\hline & & & & $\begin{array}{l}34.2 \mathrm{Mb} \text { copy number gain in } \\
12 \mathrm{p} 13.33-\mathrm{p} 11.1 \text {, pathogenic }\end{array}$ & & \\
\hline \multirow[t]{3}{*}{2} & \multirow[t]{3}{*}{ Mild } & \multirow[t]{3}{*}{ Isolated } & \multirow[t]{3}{*}{$\begin{array}{l}\text { 46,XY,der(11)t(7;11) } \\
\text { (p15;q25)mat }\end{array}$} & $\begin{array}{l}\text { arr[hg19] } \\
\text { 7p22.3p15.1(41,243-28,230,741)×3, } \\
\text { 11q25(131,526,722-134,928,850)×1 }\end{array}$ & \multirow[t]{3}{*}{ TOP } & \multirow[t]{3}{*}{ NA } \\
\hline & & & & $\begin{array}{l}28.19 \mathrm{Mb} \text { copy gain in } 7 \mathrm{p} 22.3-\mathrm{p} 15.1 \text {, } \\
\text { pathogenic }\end{array}$ & & \\
\hline & & & & $3.40 \mathrm{Mb}$ copy loss in $11 \mathrm{q} 25$, pathogenic & & \\
\hline \multirow[t]{2}{*}{$3^{*}$} & \multirow[t]{2}{*}{ Mild } & \multirow[t]{2}{*}{ Isolated } & \multirow[t]{2}{*}{$46, X Y$} & $\begin{array}{l}\text { arr[hg19] } \\
\text { 11p15.5(215049_280831×4,2468416×2) }\end{array}$ & \multirow[t]{2}{*}{ Live birth } & \multirow[t]{2}{*}{ Normal } \\
\hline & & & & $\begin{array}{l}66 \mathrm{~kb} \text { copy number gain in } 11 \mathrm{p} 15.5 \text {, } \\
\text { VOUS }\end{array}$ & & \\
\hline \multirow[t]{2}{*}{$4^{*}$} & \multirow[t]{2}{*}{ Moderate } & \multirow[t]{2}{*}{ Isolated } & \multirow[t]{2}{*}{$46, X Y$} & $\begin{array}{l}\text { arr[hg19] } \\
2 p 24.1(19,910,421-21,018,220) \times 1\end{array}$ & \multirow[t]{2}{*}{ Live birth } & \multirow[t]{2}{*}{ Delay } \\
\hline & & & & $\begin{array}{l}1.1 \mathrm{Mb} \text { copy number loss in } 2 \mathrm{p} 24.1 \text {, } \\
\text { VOUS }\end{array}$ & & \\
\hline \multirow[t]{2}{*}{$5^{\star}$} & \multirow[t]{2}{*}{ Severe } & \multirow[t]{2}{*}{ Isolated } & \multirow[t]{2}{*}{$46, X X$} & $\operatorname{arr}[G R C h 37] 17 p 13.3\left(53026 \_2251121\right) \times 1$ & \multirow[t]{2}{*}{ Live birth } & \multirow[t]{2}{*}{ Delay } \\
\hline & & & & $\begin{array}{l}2.2 \mathrm{Mb} \text { copy number loss in } 17 \mathrm{p} 13.3 \text {, } \\
\text { pathogenic, encompasses } Y W H A E \text { and } \\
\text { CRK genes }\end{array}$ & & \\
\hline 6 & Mild & $\begin{array}{l}\text { Early-onset IUGR, } \\
\text { abnormal posture }\end{array}$ & $69, X X X$ & NA & TOP & NA \\
\hline 7 & Mild & $\begin{array}{l}\text { Hypoplastic left heart, } \\
\text { bilateral cleft lip }\end{array}$ & $47, X Y,+13$ & NA & TOP & NA \\
\hline 8 & Mild & $1 \mathrm{~A} 1 \mathrm{~V}$ & $47, X Y,+18$ & NA & TOP & NA \\
\hline 9 & Mild & PLSVC, ARSA & $47, X Y,+21$ & NA & Live birth & Delay \\
\hline \multirow[t]{2}{*}{10} & \multirow[t]{2}{*}{ Mild } & \multirow[t]{2}{*}{ Left duplex kidney, VSD } & $\begin{array}{l}\operatorname{mos} \\
47, X X,+9[8] / 46, X X[16]\end{array}$ & $\begin{array}{l}\text { arr[hg19] } \\
9 p 24.3 q 34.3(163,131-141,073,897) \times 2 \sim 3\end{array}$ & TOP & NA \\
\hline & & & & $\begin{array}{l}141 \mathrm{Mb} \text { copy number gain in 9p24.3- } \\
9 \mathrm{q} 34.3 \text {, pathogenic }\end{array}$ & & \\
\hline $11^{*}$ & Mild & $\begin{array}{l}\text { ACC, heart asymmetry, } \\
\text { intra-abdominal cyst, }\end{array}$ & $46, X X$ & $\begin{array}{l}\operatorname{arr}[G R C h 37] \\
7 p 11.2 q 11.21\left(57595596 \_63408277\right) \times 3\end{array}$ & TOP & NA \\
\hline & & dilated renal pelvis & & $\begin{array}{l}5.81 \mathrm{Mb} \text { copy gain in } 7 \mathrm{p} 11.2-\mathrm{q} 11.21 \\
\text { VOUS }\end{array}$ & & \\
\hline 12 & Moderate & $\begin{array}{l}\text { Abnormal facial profile, } \\
\text { VSD, } 1 \mathrm{~A} 1 \mathrm{~V} \text {, rocker }\end{array}$ & 46,XX,del(1)(p36.1) & $\begin{array}{l}\text { arr[hg19] } \\
\text { 1p36.33p36.12(835,601-20,450,944)×1 }\end{array}$ & TOP & NA \\
\hline & & bottom feet & & $\begin{array}{l}\text { 19.62 Mb terminal deletion in } \\
\text { 1p36.33-p36.12, pathogenic }\end{array}$ & & \\
\hline $13^{\star}$ & Moderate & $\begin{array}{l}\text { Dandy-Walker } \\
\text { malformation }\end{array}$ & $46, X X$ & $\begin{array}{l}\operatorname{arr}[G R C h 37] \\
6 \text { p25.3p25.2(205523_2932655)×1 }\end{array}$ & TOP & NA \\
\hline & & & & $\begin{array}{l}2.73 \mathrm{Mb} \text { copy loss in 6p25.3-p25.2, } \\
\text { pathogenic, encompasses FOXC1 gene }\end{array}$ & & \\
\hline $14^{\star}$ & Moderate & Lissencephaly & $46, X X$ & $\begin{array}{l}\text { arr [GRCh37]17p13.3(1658570×2, } \\
\left.1684517 \_2931930 \times 1,2995336 \times 2\right)\end{array}$ & $\begin{array}{l}\text { Feticide outside } \\
\text { Hong Kong at } 34\end{array}$ & NA \\
\hline & & & & $\begin{array}{l}\text { 1.2 Mb loss in 17p13.3, pathogenic, } \\
\text { encompasses LIS1 gene }\end{array}$ & weeks & \\
\hline
\end{tabular}

Abbreviations: IAIV = one artery one vein of umbilical vessels; $\mathrm{ACC}=$ agenesis of corpus callosum; $\mathrm{ARSA}=$ aberrant right subclavian artery; $\mathrm{CMA}=$ chromosomal microarray analysis; IUGR = intrauterine growth restriction; NA = not available; PLSVC = persistent left superior vena cava; TOP = termination of pregnancy; VOUS = variant of uncertain significance; VSD = ventricular septal defect

* Cases which had abnormal copy number variations that were detected by CMA but not by karyotype

\section{Discussion}

\section{Summary}

The incidence of fetal ventriculomegaly in our cohort was $0.16 \%$, reflecting the incidence of fetal ventriculomegaly detectable antenatally with midtrimester morphology ultrasound examinations in a large cohort in Hong Kong. Our findings 
were compatible with previous reports of fetal ventriculomegaly incidence, which has ranged from 0.3 to 3.8 per 1000 pregnancies. ${ }^{7,8}$ While congenital infection screening was conducted in only $66.7 \%$ of our cases, no cases of intrauterine cytomegalovirus or toxoplasmosis infection were identified in our cohort. This is potentially because Chinese pregnant women have a high cytomegalovirus seroprevalence ${ }^{9}$ but a low prevalence of toxoplasmosis, compared with Caucasian pregnant women. ${ }^{10}$ Because even mild isolated ventriculomegaly $<12 \mathrm{~mm}$ carried a $12.0 \%$ risk of chromosomal abnormalities, the findings of amniocentesis with CMA appeared to be clinically meaningful, regardless of the degree of fetal ventriculomegaly. In this study, isolated mild ventriculomegaly was associated with a normal outcome in approximately $90 \%$ of children, but the risk of developmental delay increased with increasing degree of ventriculomegaly.

\section{Risk of cerebral ventriculomegaly according to sex}

Cerebral ventriculomegaly was more prevalent in male fetuses than in female fetuses in our cohort; the male to female ratio was 1.7. This finding is consistent with the results of previous studies, which demonstrated a male predominance regarding isolated cerebral ventriculomegaly (male to female ratio of 1.7). ${ }^{11}$ A study of isolated fetal ventriculomegaly in China showed no differences in chromosomal abnormalities between male and female fetuses $(7.6 \%$ vs $8.0 \%, \mathrm{P}=0.924) .{ }^{12}$ Our cohort demonstrated no significant difference in the risk of developmental delay according to fetal sex in cases of isolated ventriculomegaly. Previous studies also showed no significant differences in neurological outcomes between male and female infants with isolated ventriculomegaly and normal karyotype. ${ }^{11}$ Further studies are needed to explore the reason for a higher incidence of cerebral ventriculomegaly in male fetuses than in female fetuses.

\section{Comparison of karyotype and chromosomal microarray analysis}

The incidence of an abnormal karyotype (11.4\% overall vs $8.0 \%$ in the mild isolated group) in our cohort was similar to the results of previous studies. Previous studies with differences in the proportions of cases with each degree of ventriculomegaly, as well as the proportions of associated abnormalities, demonstrated that the incidence of an abnormal karyotype in cases of fetal ventriculomegaly was between $5 \%$ and $11.3 \% .{ }^{13-15}$ In a systematic review of isolated ventriculomegaly (10-15 mm), 4.7\%(57/1213) of fetuses had abnormal karyotype results. ${ }^{16}$ Another prospective study, which included 355 cases of mild to moderate ventriculomegaly, showed a higher rate of abnormal karyotype results when other structural
TABLE 3. Incidences of abnormal karyotype or CMA results according to the degree of isolated cerebral ventriculomegaly*

\begin{tabular}{lccc}
\hline $\begin{array}{l}\text { Degree of isolated } \\
\text { ventriculomegaly }\end{array}$ & $\begin{array}{c}\text { Normal karyotype/ } \\
\text { CMA }\end{array}$ & $\begin{array}{c}\text { Abnormal } \\
\text { karyotype/CMA }\end{array}$ & P value $^{\dagger}$ \\
\hline Mild $(10-11.9 \mathrm{~mm})$ & $22 / 25(88.0 \%)$ & $3 / 25(12.0 \%)$ & 0.31 \\
\hline Moderate $(12-14.9 \mathrm{~mm})$ & $5 / 6(83.3 \%)$ & $1 / 6(16.7 \%)$ & \\
Severe $(\geq 15 \mathrm{~mm})$ & $1 / 2(50.0 \%)$ & $1 / 2(50.0 \%)$ & \\
\hline
\end{tabular}

Abbreviation: CMA = chromosomal microarray analysis

Data are shown as No. (\%), unless otherwise specified

Fisher's exact test

TABLE 4. The incidence of developmental delay according to the degree of ventriculomegaly, karyotype/CMA results and fetal sex of isolated cerebral ventriculomegaly $(n=43)^{*}$

\begin{tabular}{lrcc}
\hline Risk factors & $\begin{array}{c}\text { Normal } \\
\text { development }\end{array}$ & $\begin{array}{c}\text { Developmental } \\
\text { delay }\end{array}$ & P value $^{\dagger}$ \\
\hline Degree of ventriculomegaly & $28(90.3 \%)$ & $3(9.7 \%)$ & 0.03 \\
\hline Mild (10.0-11.9 mm) & $7(58.3 \%)$ & $5(41.7 \%)$ & \\
Non-mild ( $\geq 12 \mathrm{~mm})$ & & & 0.09 \\
Karyotype/CMA results & $23(85.2 \%)$ & $4(14.8 \%)$ & \\
Normal & $1(33.3 \%)$ & $2(66.7 \%)$ & 0.42 \\
\hline Abnormal & & & \\
\hline Fetal sex & $24(85.7 \%)$ & $4(14.3 \%)$ & \\
\hline Male & $11(73.3 \%)$ & $4(26.7 \%)$ & \\
Female &
\end{tabular}

Abbreviation: CMA = chromosomal microarray analysis

Data are shown as No. (\%), unless otherwise specified. Total number of live births that could report neurodevelopmental outcomes in cases of isolated ventriculomegaly was 43

Fisher's exact test

abnormalities were present (18.0\%), compared with the isolated ventriculomegaly group (10.2\%).

Chromosomal microarray analysis testing provided an incremental diagnostic yield of $8.6 \%$, compared with conventional karyotyping in our cohort; $4.3 \%$ of cases exhibited pathogenic CNVs, while $4.3 \%$ of cases exhibited VOUS. Chromosomal microarray analysis can identify aneuploidies (ie, large structural chromosomal changes); it can also identify submicroscopic $(<5 \mathrm{Mb}) \mathrm{CNVs}$ that cannot be detected by conventional karyotyping. ${ }^{17}$ Recent studies have focused on the application of CMA for detecting chromosomal aberrations in cases of fetal cerebral ventriculomegaly. The incremental diagnostic yields of CMA over karyotyping for diagnosing pathogenic CNVs and VOUS in previous studies of fetal cerebral ventriculomegaly conducted in China were $3.0 \%$ to $12.8 \%$ and $2.0 \%$ to $4.5 \%$, respectively. ${ }^{18-21}$ A limitation of CMA testing is the reporting of VOUS, which poses counselling difficulties during subsequent management. In a recent cohort in Hong Kong, the rate of VOUS was $2.1 \%$ in prenatal samples obtained for various 
TABLE 5. Clinical details of the 12 cases with developmental delay

\begin{tabular}{|c|c|c|c|c|c|c|}
\hline Case & $\begin{array}{l}\text { Degree of } \\
\text { fetal ventri- } \\
\text { culomegaly }\end{array}$ & $\begin{array}{l}\text { Prenatal structural } \\
\text { abnormalities }\end{array}$ & Karyotype/CMA result & $\begin{array}{l}\text { Age at } \\
\text { assessment, } \\
\text { mo }\end{array}$ & $\begin{array}{l}\text { Postnatal imaging and } \\
\text { intervention }\end{array}$ & Development \\
\hline 1 & Mild & Isolated & NA & 72 & $\begin{array}{l}\text { MRI brain: asymmetrical ventricular } \\
\text { system with slightly larger left } \\
\text { frontal horn, no focal lesion }\end{array}$ & Mild global delay \\
\hline 2 & Mild & Isolated & Normal & 48 & $\begin{array}{l}\text { MRI brain: ganglioglioma in left } \\
\text { temporal lobe }\end{array}$ & $\begin{array}{l}\text { Epilepsy, autism } \\
\text { spectrum disorder, } \\
\text { speech delay }\end{array}$ \\
\hline 3 & Mild & Isolated & Normal & 25 & US brain: normal & Mild speech delay \\
\hline 4 & Moderate & $\begin{array}{l}\text { Isolated (fetal MRI } \\
\text { brain: germinal matrix } \\
\text { haemorrhage) }\end{array}$ & Normal & 36 & $\begin{array}{l}\text { MRI brain: previous germinal matrix } \\
\text { haemorrhage, small left middle } \\
\text { cranial fossa arachnoid cyst }\end{array}$ & $\begin{array}{l}\text { Mild gross motor } \\
\text { delay }\end{array}$ \\
\hline 5 & Moderate & Isolated & 2p24.1 deletion (VOUS) & 48 & $\begin{array}{l}\text { US brain: mildly dilated lateral } \\
\text { ventricles, no other abnormalities }\end{array}$ & $\begin{array}{l}\text { Mild speech and } \\
\text { motor delay, autism } \\
\text { spectrum disorder }\end{array}$ \\
\hline 6 & Moderate & Isolated & $\begin{array}{l}\text { Normal (methylation } \\
\text { test after delivery led to } \\
\text { diagnosis of Beckwith- } \\
\text { Wiedemann syndrome) }\end{array}$ & 29 & CT brain: normal & Mild global delay \\
\hline 7 & Severe & Isolated & NA & 60 & $\begin{array}{l}\text { US brain: left ventriculomegaly } \\
\text { resolved, tiny subependymal cyst } \\
\text { at left ventricle }\end{array}$ & Global delay, epilepsy \\
\hline 8 & Severe & Isolated & $\begin{array}{l}17 \mathrm{p} 13.3 \text { deletion } \\
\text { (pathogenic) }\end{array}$ & 36 & $\begin{array}{l}\text { MRI brain: mildly prominent } \\
\text { ventricles, tiny Rathke's cleft cyst, } \\
\text { no other abnormalities }\end{array}$ & $\begin{array}{l}\text { Intellectual disability, } \\
\text { speech delay }\end{array}$ \\
\hline 9 & Mild & PLSVC, ARSA & Trisomy 21 & 25 & NA & Mild global delay \\
\hline 10 & Mild & $\begin{array}{l}\text { Absent cavum septum } \\
\text { pellucidum (fetal } \\
\text { MRI brain: ischemic } \\
\text { changes or cystic } \\
\text { encephalomalacia) }\end{array}$ & $\begin{array}{l}\text { Normal (postnatal WES } \\
\text { detected homozygous } \\
\text { SCO2 mutation) }\end{array}$ & 14 & $\begin{array}{l}\text { US brain: periventricular } \\
\text { leukomalacia } \\
\text { MRI brain: old haemorrhagic insult }\end{array}$ & Global delay \\
\hline 11 & Moderate & TOF & Normal & $\begin{array}{l}15 \text { (preterm } \\
\text { delivery at } \\
32 \text { weeks) }\end{array}$ & $\begin{array}{l}\text { CT brain: symmetrical } \\
\text { periventricular hypodense areas } \\
\text { suggest previous ischaemic insult } \\
\text { Operation for TOF conducted }\end{array}$ & Mild global delay \\
\hline 12 & Severe & $\begin{array}{l}\text { Myelomeningocele } \\
\text { (with fetoscopic repair) }\end{array}$ & Normal & 16 & $\begin{array}{l}\text { MRI brain and spine: persistent } \\
\text { low-lying cord and upper } \\
\text { syringomyelia, hydrocephalus with } \\
\text { aqueduct stenosis } \\
\text { VP shunt inserted and operation for } \\
\text { cord tethering performed }\end{array}$ & Gross motor delay \\
\hline
\end{tabular}

Abbreviations: $\mathrm{ARSA}=$ aberrant right subclavian artery; $\mathrm{CMA}=$ chromosomal microarray analysis; $\mathrm{CT}=$ computed tomography; $\mathrm{MRI}=$ magnetic resonance imaging; NA = not available; PLSVC = persistent left superior vena cava; TOF = Tetralogy of Fallot; US = ultrasound;VOUS = variant of uncertain significance; $\mathrm{VP}=$ ventriculoperitoneal; WES = whole-exome sequencing

indications (eg, abnormal ultrasound, positive Down syndrome screening, abnormal non-invasive prenatal testing, advanced maternal age, and family history of chromosomal/genetic disorders). ${ }^{22}$ Our cohort detected $4.3 \%$ of VOUS, which is high but generally comparable with the findings of previous studies.

Consistent with our findings, the incidences of abnormal karyotype or CMA results in previous studies did not significantly differ according to the degree of cerebral ventriculomegaly. ${ }^{23,24}$ Therefore, invasive diagnostic tests are warranted for any degree of cerebral ventriculomegaly identified in prenatal ultrasound, including mild isolated ventriculomegaly. Chromosomal microarray analysis should be performed because of its higher diagnostic yield, compared with conventional karyotyping. The Hospital Authority of Hong Kong has replaced conventional karyotyping with CMA as the primary test for chromosomal studies of structural abnormalities detected in prenatal ultrasound since June 2019. Therefore, the incidences of chromosomal abnormalities detected in fetal cerebral ventriculomegaly are expected to increase in the future. Non-invasive prenatal testing for chromosomal abnormalities by maternal blood DNA testing is a trend among pregnant women because of its non-invasiveness. However, noninvasive prenatal testing for $\mathrm{CNVs}<5 \mathrm{Mb}$ yielded a detection rate of only $14.3 \% .^{25}$ The above findings 
suggest that non-invasive prenatal testing should not be offered as an alternative for women with fetal cerebral ventriculomegaly, regardless of the degree of ventriculomegaly, because small pathogenic CNVs can be present in cases that involve any degree of ventriculomegaly.

\section{Role of genetic mutations in fetal ventriculomegaly}

One of the fetuses in our cohort had mild cerebral ventriculomegaly; MRI of the brain revealed ischaemic changes (Table 5 Case 10). Amniocentesis was performed and showed normal karyotype and CMA results. The baby had progressive hypertrophic cardiomyopathy with global developmental delay after delivery. Trio whole-exome sequencing (WES) was done after delivery, and the baby was diagnosed with autosomal recessive mitochondrial disease caused by $\mathrm{SCO} 2$ mutations; both parents were heterozygous carriers. In prenatal fetal structural abnormalities, WES can reveal a high proportion of diagnostic genetic variants, including up to $22 \%$ in CNS abnormalities including cerebral ventriculomegaly. ${ }^{26}$ Mutations in two X-linked genes ( $L 1 C A M$ and $A P 1 S 2$ ) and two autosomal recessive genes $(C C D C 88 C$ and $M P D Z$ ) have been described to cause congenital hydrocephalus or aqueductal stenosis, which can cause severe isolated ventriculomegaly. ${ }^{27}$ There is a potential role for WES in facilitating the genetic diagnosis in cerebral ventriculomegaly with negative karyotype and CMA results, particularly for those fetuses with severe ventriculomegaly suggestive of aqueductal stenosis and in couples with recurrent fetal abnormalities.

\section{Risk of developmental delay according to the degree of ventriculomegaly}

Fetal cerebral ventriculomegaly was associated with an increased risk of developmental delay in the child after delivery. The neurodevelopmental prognosis worsened as the degree of ventriculomegaly increased in our cohort $(9.7 \%$ in cases of mild ventriculomegaly vs $41.7 \%$ in cases of moderate or severe ventriculomegaly) and in other studies. In a systematic review and meta-analysis of neurodevelopmental outcomes in cases of isolated ventriculomegaly $(10-15 \mathrm{~mm})$, the overall prevalence of developmental delay was $7.9 \% .{ }^{16}$ In a meta-analysis of the neurological outcomes of fetal ventriculomegaly in China, the neurological prognosis was good in $88 \%, 57 \%$, and $36 \%$ of mild, moderate, and severe ventriculomegaly cases, respectively. ${ }^{13}$ In another systematic review and meta-analysis of severe isolated ventriculomegaly, developmental delay was mild or moderate in $18.6 \%$ of children and severe in $39.6 \%$ of children. ${ }^{28}$ More than half $(58.3 \%, 7 / 12)$ of the children diagnosed with developmental delay in our study exhibited only mild delay, although there was a background risk of mild developmental delay during counselling. The high incidence of developmental delay in cases of non-mild isolated ventriculomegaly was probably also associated with the presence of chromosomal abnormalities. Nevertheless, our data did not show associations of abnormal karyotype or CMA results with developmental delay among the 43 live births. This finding was presumably biased because pregnancies were terminated in many of the cases with abnormal karyotype or CMA results; the neurological outcomes could not be assessed in those cases.

\section{Strengths and limitations}

This study had some limitations. First, it used a retrospective cohort design; thus, congenital infection screening and fetal MRI assessment were not performed in all cases. Second, there was no protocol for routine postnatal imaging evaluation, and the assessment of neurodevelopmental outcomes among the children was not standardised. However, our study provided data regarding the incidences of chromosomal and genetic abnormalities in cases of antenatally detected fetal ventriculomegaly in Hong Kong, as well as a general picture of neurological outcomes of affected children. The findings will allow prenatal counselling in Hong Kong to be performed on the basis of more relevant epidemiological and genomic data, rather than findings from other populations.

\section{Conclusion}

All degrees of cerebral ventriculomegaly may be associated with chromosomal abnormalities. Chromosomal microarray analysis has an increased diagnostic yield, compared with conventional karyotyping. Amniocentesis with CMA testing should be offered to all women with fetal cerebral ventriculomegaly. Non-invasive prenatal testing should not be offered as an alternative method of chromosomal analysis. The neurological outcomes of the children are associated with the degree of fetal ventriculomegaly. Whole-exome sequencing may be indicated for selected cases of fetal ventriculomegaly with normal CMA, but further studies are needed to support this recommendation.

\section{Author contributions}

Concept or design: WY Lok, CW Kong, WK To. Acquisition of data: WY Lok, MM Shi, SYA Hui.

Analysis or interpretation of data: WY Lok, CW Kong, WK To.

Drafting of the manuscript: WY Lok, CW Kong.

Critical revision of the manuscript for important intellectual content: All authors. 
All authors had full access to the data, contributed to the study, approved the final version for publication, and take responsibility for its accuracy and integrity.

\section{Conflicts of interest}

All authors have disclosed no conflicts of interest.

\section{Funding/support}

This research received no specific grant from any funding agency in the public, commercial, or not-for-profit sectors.

\section{Ethics approval}

Ethics approval was obtained from the Kowloon Central/ Kowloon East Research Ethics Committees (Ref: KC/KE19-0172/ER-4) and The Joint Chinese University of Hong Kong-New Territories East Cluster Clinical Research Ethics Committee (CREC Ref No.: 2019.468).

\section{References}

1. alomon LJ, Alfirevic Z, Berghella V, et al. Practice guidelines for performance of the routine mid-trimester fetal ultrasound scan. Ultrasound Obstet Gynecol 2011;37:11626.

2. International Society of Ultrasound in Obstetrics \& Gynecology Education Committee. Sonographic examination of the fetal central nervous system: guidelines for performing the 'basic examination' and the 'fetal neurosonogram.' Ultrasound Obstet Gynecol 2007;29:10916.

3. Cardoza JD, Goldstein RB, Filly RA. Exclusion of fetal ventriculomegaly with a single measurement: the width of the lateral ventricular atrium. Radiology 1988;169:711-4.

4. Society for Maternal-Fetal Medicine (SMFM); Fox NS, Monteagudo A, Kuller JA, Craigo S, Norton ME. Mild fetal ventriculomegaly: diagnosis, evaluation, and management. Am J Obstet Gynecol 2018;219:B2-9.

5. Online Mendelian Inheritance in Man. \#247200 MillerDieker Lissencephaly Syndrome. Available from: https:// www.omim.org/entry/247200. Accessed 1 Aug 2020.

6. Online Mendelian Inheritance in Man. "601090 FORKHEAD BOX C1; FOXC1. Available from: https:// www.omim.org/entry/601090. Accessed 1 Aug 2020.

7. Weichert J, Hartge D, Krapp M, Germer U, Gembruch U, Axt-Fliedner R. Prevalence, characteristics and perinatal outcome of fetal ventriculomegaly in 29,000 pregnancies followed at a single institution. Fetal Diagn Ther 2010;27:142-8

8. Patel SK, Zamorano-Fernandez J, Nagaraj U, Bierbrauer KS, Mangano FT. Not all ventriculomegaly is created equal: diagnostic overview of fetal, neonatal and pediatric ventriculomegaly. Childs Nerv Syst 2020;36:1681-96.

9. Wang S, Wang TZ, Zhang WQ, et al. Cohort study on maternal cytomegalovirus seroprevalence and prevalence and clinical manifestations of congenital infection in China. Medicine (Baltimore) 2017;96:e6007.

10. Ko RC, Wong FW, Todd D, Lam KC. Prevalence of Toxoplasma gondii antibodies in the Chinese population of Hong Kong. Trans R Soc Trop Med Hyg 1980;74:351-4.

11. Melchiorre K, Bhide A, Gika AD, Pilu G, Papageorghiou AT. Counseling in isolated mild fetal ventriculomegaly.
Ultrasound Obstet Gynecol 2009;34:212-24

12. Zhao D, Cai A, Wang B, Lu X, Meng L. Presence of chromosomal abnormalities in fetuses with isolated ventriculomegaly on prenatal ultrasound in China. Mol Genet Genomic Med 2018;6:1015-20.

13. Sun Y, Zhang WY. Meta-analysis of fetal lateral ventriculomegaly and prognosis [in Chinese]. Zhonghua Fu Chan Ke Za Zhi 2018;53:677-82.

14. Gezer C, Ekin A, Ozeren M, et al. Chromosome abnormality incidence in fetuses with cerebral ventriculomegaly. J Obstet Gynaecol 2014;34:387-91.

15. Bijarnia-Mahay S, Puri RD, Kotecha U, et al. Outcome of prenatally-detected fetal ventriculomegaly. J Fetal Med 2015;2:39-44.

16. Pagani G, Thilaganathan B, Prefumo F. Neurodevelopmental outcome in isolated mild fetal ventriculomegaly: systematic review and meta-analysis. Ultrasound Obstet Gynecol 2014;44:254-60.

17. Chau MH, Cao Y, Kwok YK, et al. Characteristics and mode of inheritance of pathogenic copy number variants in prenatal diagnosis. Am J Obstet Gynecol 2019;221:493. e1-e11.

18. Duan HL, Zhu XY, Zhu YJ, et al. The application of chromosomal microarray analysis to the prenatal diagnosis of isolated mild ventriculomegaly. Taiwan J Obstet Gynecol 2019;58:251-4

19. He M, Hu S, Hu T, Zhang Z, Luo H. Correlation between fetal borderline ventriculomegaly and chromosomal abnormalities [in Chinese]. Zhonghua Fu Chan Kae Za Zhi 2018;53:660-4.

20. Song TT, Wan SN, LI Y, et al. Application value of chromosomal microarray analysis in prenatal diagnosis of lateral ventriculomegaly fetuses [in Chinese]. PLAMJ Med J Chi People Liberation Army 2017;42:902-8.

21. Li ZZ, Fu F, Lei TY, et al. Application of chromosome microarray analysis for the delineation of pathogenesis for fetal ventriculomegaly [in Chinese]. Zhonghua Yi Xue Yi Chuan Xue Za Zhi 2017;34:576-82.

22. Cheng SS, Chan KY, Leung KK, et al. Experience of chromosomal microarray applied in prenatal and postnatal settings in Hong Kong. Am J Med Genet C Semin Med Genet 2019;181:196-207.

23. Zhang ZQ, Xie YJ, Wu JZ, et al. Chromosomal microarray analysis for lateral ventriculomegaly in fetus [in Chinese]. Zhonghua Yi Xue Yi Chuan Xue Za Zhi 2015;32:789-92.

24. Peng YX, Qiu YW, Chang QX, Yu YH, Zhang M, Li KR. Clinical value of genome-wide chromosome microarray technique in diagnosis of fetal cerebral ventriculomegaly [in Chinese]. Nan Fang Yi Ke Da Xue Xue Bao 2018;38:3537.

25. Li R, Wan J, Zhang Y, et al. Detection of fetal copy number variants by non-invasive prenatal testing for common aneuploidies. Ultrasound Obstet Gynecol 2016;47:53-7.

26. Petrovski S, Aggarwal V, Giordano JL, et al. Whole-exome sequencing in the evaluation of fetal structural anomalies: a prospective cohort study. Lancet 2019;393:758-67.

27. Kousi M, Katsanis N. The genetic basis of hydrocephalus. Annu Rev Neurosci 2016;39:409-35.

28. Carta S, Agten AK, Belcaro C, Bhide A. Outcome of fetuses with prenatal diagnosis of isolated severe bilateral ventriculomegaly: systematic review and meta-analysis. Ultrasound Obstet Gynecol 2018;52:165-73. 